\title{
Limits of Freedom - Defining a Normative Background for Spatial Citizenship
}

\author{
Inga Gryl, Denise Könen and Jana Pokraka \\ University of Duisburg-Essen
}

\begin{abstract}
This paper deals with the application of geomedia that are in everyday use, quoting two highly political mapping examples. These publicly accessible digital maps addressing the current refugee situation, its reception and instrumentalization in Germany are used to provide a vivid example of a practical application of Spatial Citizenship. This paper presents the theoretical framework of Spatial Citizenship. After examining questions which arise from an analysis of the maps, this framework is discussed and extended, especially with regards to the social embeddedness of its basic principles of fundamental human rights and democratic negotiation. The discussion reveals the links between approaches from social geography and central aspects of citizenship education. Finally, the educational implications of this extension of the Spatial Citizenship approach are discussed while presenting a practical example.
\end{abstract}

\section{Key words}

Spatial Citizenship, geography education, racism, critical cartography, geomedia

\section{Introduction: refugee-related mapping and Spatial Citizenship}

Recently, two neocartography maps (i.e. maps produced by lay cartographers) appeared on the platform Google My Maps. Remarkably, both attracted considerable public attention and provoked headlines (Friz, 2015; Hollmer, 2015; Schulz, 2015; Reinbold, 2015), while providing very different perspectives on one and the same topic, namely the situation of refugees in Germany, or, from a meta-perspective, the way this situation is handled by society. The first map was published in 2015, captioned 'No asylum-seeker accommodation in my neighbourhood', while its later version has the caption 'Help people in need' (authors' translations). Both maps contain(ed) location and other information on refugee shelters, as well as a public call for the map's completion. Many critics regarded the call as an invitation for racist assaults, particularly since violent attacks on refugee shelters have increased steadily in Germany over the past few years (BMI, 2015). The second map, named 'Hoaxmap' (Figure 2) by its creators, aims to disprove false rumors about criminal offences allegedly committed by refugees, and is thus situated within the current debate on fake news. Both maps clearly show how the linkages between (digital) geomedia and political activity have 
entered everyday life.

When it comes to geomedia education, these linkages require a closer look. Within this paper, the Spatial Citizenship approach (Gryl \& Jekel, 2012; Jekel et al., 2015), which aims to promote the participation of mature citizens (see Section 3 below) in social communication and decision-making processes by competitive web-based geomedia production, is used as a theoretical as well as an applied framework to analyse the maps and the corresponding practices. We will argue that, despite the clear link between both maps and societal and political issues, only one of the maps meets the criteria inherent in Spatial Citizenship, which is based on fundamental human rights and democracy (Schulze et al. 2015). Taking a closer look at the two examples (Section 2), we will enrich the theoretical basis of the Spatial Citizenship approach (briefly explained in Section 3) concerning human rights and the term 'democratic negotiation' (Section 4). Finally, we will apply this theoretical framework within a practically-approved learning environment (Section 5).

\section{Setting the scene: two examples of the everyday use of geomedia}

The first of the two examples presented here is the 'Nazi map' (Figure 1), the original stated intention of which was to reveal the amount of refugee accommodation in Germany. According to the map's description, a contribution to the map's content was possible by sending an e-mail to its editors. The map could be shared over social media; disseminating it thus posed a potential risk to inhabitants of refugee shelters by providing sensitive data, such as the number and sex of the refugees being housed. After massive public protests, Google finally blocked access to the map (see Zeit Online 2015). In response, a new map with almost identical content was launched, under the heading 'Help people in need'. In view of the map's description (We will accept updates of the map "No asylum-seeker accommodation in my neighborhood";' authors' translation) and the mainly pejorative descriptions of the individual homes and their inhabitants, it is clear that the intentions of both versions are the same. The modes of expansion and distribution also remain identical. It is obvious that this map follows a political strategy using design and geoweb options in an attention-seeking and emotive manner, trying to convince people of the alleged acceptability of a nationalistic or xenophobic mindset, and potentially encouraging violent action in response. Therefore, we regard the name 'Nazi map' as justified. 


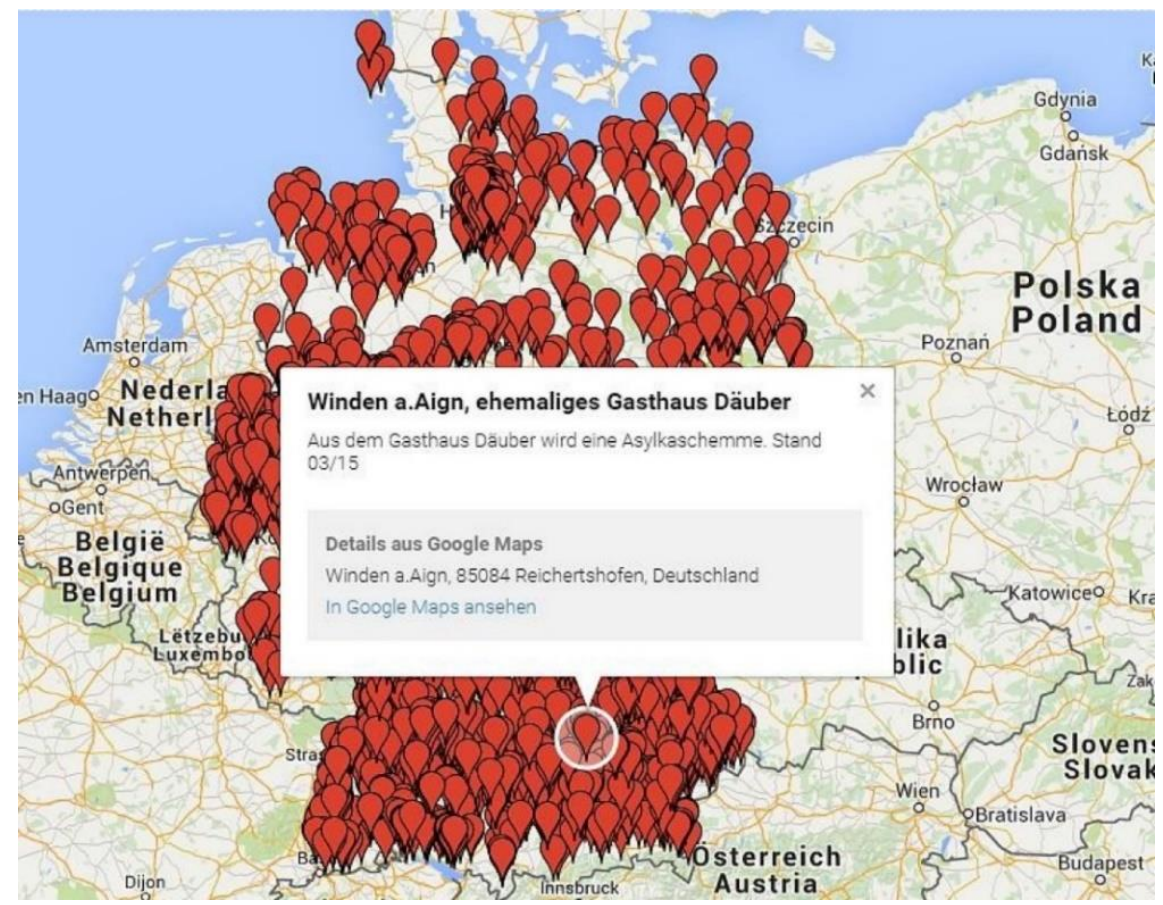

Figure 1: 'Nazi map', with one derogatory comment of many, saying: 'Guesthouse Dübner becomes an asylum honky-tonk' (Google Maps

Screenshot)https://www.google.com/maps/d/u/0/viewer?mid=zORwXmZ9W1Fl.k5Q5YrMM3Bf8, 17.08.2015).

With the emergence of a multiplicity of public communication channels and sources of information, counter-mapping is not only a map-based form of communication against the dominant spatial construction of the powerful (Peluso, 1995) but also a useful instrument against the dominant societal constructions of space (Albernathy ,2017). In this context, we see the 'Hoaxmap' (Figure 2) from 2016 as a fine example of counter-mapping to challenge the feelings of threat and fear which the authors of the 'Nazi map' try to evoke. Contrasting with the multitude of rumors about crimes committed by refugees which are shared and duplicated on the Internet, particularly through social networks, the Hoaxmap was developed primarily in order to disprove the scattered rumors. The Hoaxmap shows where a criminal offence is said to have been committed and gives a link to a rectification report, mostly in the form of a regional (or sometimes national) press article. Information is added to this project via Twitter or e-mail. This example of refugee-related mapping shows how political awareness can help to handle new societal, media-linked challenges brought about by information technologies. Influencing the debate requires the mature application of those technologies themselves. 


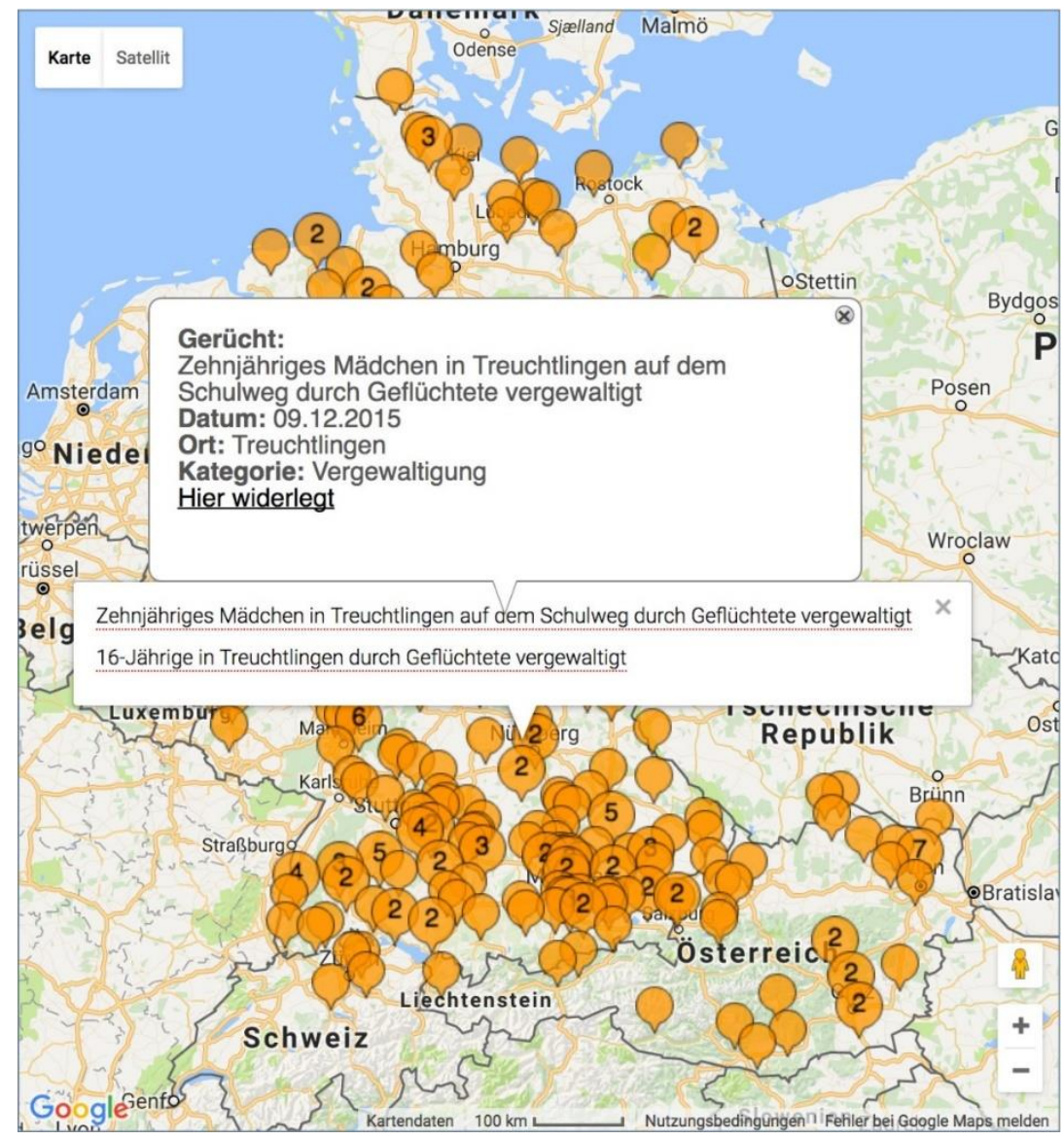

Figure 2: 'Hoaxmap', with one exemplary comment saying: 'rumor: 10-year-old girl raped by refugees on her way to school, 9.12.2015, Treuchtlingen, category. Rape. Here disproved (link to press source).' (Screenshot http://hoaxmap.org, 09.01.2017).

\section{Framework: utilizing geomedia with a Spatial Citizenship approach}

Education for Spatial Citizenship should provide students with the means to deconstruct cartographers' intentions that become visible in geomedia representations, as in the 'Nazi map', as well as to produce counter-maps that provide alternative scenarios, as in the 'Hoaxmap'. More generally speaking, the aim of Spatial Citizenship (Gryl \& Jekel, 2012; Jekel et al., 2015) is to enable every citizen to maturely appropriate public spaces and participate in spatial formation processes with the help of (digital) geomedia technologies while taking part in public spatial decision-making processes. Maturity, here, refers to the ability to act autonomously, to reflect critically upon given (e.g. social, political, economic) structures and processes; it also refers to being capable of self-determination and, if necessary, to being able to act in opposition to existing, anti-democratic tendencies (Adorno, 1971). In this context, utilizing geomedia to keep up with changing forms of (political) participation (Bennett et al., 
2009) means not only to consume but also to produce georeferenced content, therefore taking part in shaping everyday spaces. These spaces, according to social geography (Lefebvre, 1993), are products of individuals' and institutions' constructions, attached with meaning in order to secure control and power relations. Simple web-mapping tools, which we regard - despite the complexity of the term (see Gryl et al., 2017, forthcoming) - as a type of geomedia, are the adequate instruments to produce competitive, web-distributable maps and counter-maps, rather than traditional GIS. Geomedia in this sense are tools of lay cartography and allow Spatial Citizenship to be open to literally every citizen (Gryl \& Jekel, 2012). Citizenship hereby takes place within fluid entities, such as web 2.0 communities, rather than normative entities, such as nation states.

In this context, education for Spatial Citizenship (Jekel et al., 2015; Schulze et al., 2015) educates students in the following dimensions of geomedia-related competencies: (a) technology \& methodology; (b) reflection \& reflexivity; (c) communication, participation \& negotiation (Jekel et al., 2015). As illustrated in relation to the theories above, these dimensions are embedded within a spatial domain, which involves an understanding of the social construction of space, and in a citizenship education domain focusing on participatory, activist competencies and maturity (e.g. Weißeno et al., 2009; Bennett et al., 2009).

The - to us - moral superiority of the 'Hoaxmap' does not exclude it from being seen as intentionally driven. It can thus be an object of deliberate analysis using deconstruction principles. However, although both maps seek to convince others of their viewpoint of reality through the use of digital geomedia, this does not make the 'Nazi map' a product of Spatial Citizenship, because it does not follow the basic principles of democratic negotiation and fundamental human rights that are key to this approach. Section 4 will illustrate and further elaborate on these principles.

\section{Theoretical consolidation: democratic principles and human rights as the basis of the Spatial Citizenship approach}

The two examples illustrate clearly that map-making is a highly political activity, and the term 'citizenship' in the Spatial Citizenship approach underlines this observation. However, despite the variety of spatial interests, perspectives on space and therefore meanings attached to space, and in spite of all the openness in the negotiation process and the utilization of map design to argue a position and convince others, there are strict borders when it comes to being a Spatial Citizen. These borders are democratic principles of negotiation and the fundamental human rights that must be maintained (Pokraka et al., 2016; Schulze et al., 2015). While the 'Hoaxmap' is driven by these conditions, the 'Nazi map' is definitely not; it is therefore not an example of Spatial Citizenship, although its producers were able to raise public attention through the mapping. Spatial Citizenship falls squarely within political education as it follows normative guidelines that form the basis of a societal coexistence and human dignity. At the same time, it provides openness, allowing the shaping and altering of societies as well. As such, the approach follows an ideal of humanist education (Liessmann, 2011), not a praxis of neoliberal education that would focus on the preservation of systems and, concomitantly, of potential inequalities. For a humanist orientation, a certain focus is needed for the fuzzy term 'democracy'. 
A formal definition of 'democracy' is a political system in which power is exercised by the public. However, this power is generally limited, as equality of participation in decisionmaking processes is not a given (as examples such as lobbyism and pressure of wealth illustrate). By contrast, Spatial Citizenship - though it may take place within formal education - is not bound to a certain nation state but is exercised within fluid communities which are formed around a certain spatio-political issue, for instance on the web. While direct democracy is limited within most formal political systems, its principles - openness to everyone (going beyond the right to vote), discussion and negotiation (the principles of 'post-industrial democracies' in Bennett et al., 2009, p. 106) - are addressed in Spatial Citizenship. Within this approach, 'participation' refers to higher steps on the ladder of participation, i.e. processes that involve appropriation of power in decision-making processes instead of alibi-participation (Hart, 1997), involving maturity (Adorno, 1971), emancipation (Habermas, 1970) and change, based on reflexivity (Luhmann, 1998). To fulfill this aim, Spatial Citizenship has by and large to leave formal participation paths and look instead at grassroots participation (Elwood \& Mitchell, 2013).

In order to avoid humans being harmed, fundamental human rights have to be the basis of Spatial Citizenship in guiding the desired participation. This includes a balancing act between controversy (a principle of political education, see e.g. Grammes, 2005) and normative humanity. To achieve this, the Universal Declaration of Human Rights (UDHR) of the United Nations is a reasonable foundation (Pokraka et al., 2016), as it is accepted by most UN members, and its international recognition has increased (although it is not necessarily effective in national law) (Riedel, 2004). We deliberately do not regard religiously branded models of 'universal' human (or, should we say, 'men's') rights, such as the Arab Charter on Human Rights, as acceptable alternatives. The Arab Charter, for instance, says

Men and women are equal in human dignity, in rights and in duties, within the framework of the positive discrimination established in favor of women by Islamic Shari'a and other divine laws, legislation and international instruments. Consequently, each State Party to the present Charter shall undertake all necessary measures to guarantee the effective equality between men and women. (Arab Charter on Human Rights 2006, p. 151).

In labelling the unequal treatment of men and women in reference to Shari'a a 'positive discrimination', a euphemism is created. Further International Conventions such as the one on the Elimination of all forms of Racial Discrimination (CERD) consolidate, by contrast, the ideas of the UDHR. Obviously, the 'Nazi map' offends the principles of both documents, particularly Article 2 of the UDHR, banning discrimination.

We understand that all participation processes involve dilemmas, because positive outcomes for some may be negative ones for others. This, however, is basic to democracy. We are also aware that one dilemma of democracy is that it may legally undermine itself (Wirsching, 2016). Likewise, acting on a legal basis is no guarantee of ethical action. For instance, many political decisions made in the refugee debate are based not just on human rights but on economic interests too, and foster the maintaining of a certain standard of living for the nation-state's own inhabitants more than securing the refugees' lives. Furthermore, globalization is driven mainly by a neoliberal ideal of market mobility, not by supranational agreements that would enable the mobility of humans beyond the economic interest of the 
most powerful stakeholders. We know, too, that war deliberately plays with human life (particularly among the civilian population) in order to exercise pressure on political opponents (Münkler, 2002). But suppression and racism are not adequate responses to this violent situation and international political challenge. In contrast, the 'Hoaxmap' is an example of Spatial Citizenship driven by awareness of human dignity, equal human rights, reflexivity and rationality.

In sum, we can say that Spatial Citizenship - despite its aims to reshape society and socially constructed rules, and to promote dialogue and controversies on a communicative level - is not free from the normative principles that enable societal coexistence. This is the inevitable basis for its orientation towards non-violence in both communication and action. Thus, it faces the same principles as citizenship education does, which is also and necessarily not without moral principles (Johnson \& Morris 2010). Using the Spatial Citizenship approach means being aware of its strict limits while exploiting freedom on this basis. This includes being explicit regarding the limitations and precise basis of Spatial Citizenship, as well as the opportunities it affords when teaching learners to become Spatial Citizens. By taking a metaperspective, these conscious limitations of freedom should be regarded as an opportunity for reflexivity.

As Spatial Citizenship is an educational approach, a deeper perspective on human rights and democratic principles should influence its application in the classroom. The following section will provide a practical example of how this might be achieved.

\section{Educational implications: practical ideas and reflection}

The learning environment described here utilizes the 'Nazi map' and the 'Hoax map', with a particular focus on the normative background of Spatial Citizenship. It was conducted with prospective teachers for primary social and science education in a seminar called 'Society and Space' at the University of Duisburg-Essen.

Bearing Spatial Citizenship's normative principles in mind, through a process of deconstruction the 'Nazi map' can be thematized in Geography classes to reveal its producers' cover-up tactics. Critical and reflexive map-reading skills in particular are needed, due to the re-contextualization and renaming of the map. Furthermore, the map is to be decoded as a tool to convince the undecided and thoughtless. Deconstruction as a methodological starting point for talking about the 'Nazi map' in Geography teaching follows Harley's corresponding theory (1989). The focus of the seminar lies in the deconstruction of the map's alleged call for help; the aim is that the students should reach an understanding that this is a way of securing the map's continued existence, despite its repeated deletion, and that the call for help is therefore a means of continuing to gather information on refugees' shelters that may be used to harm their inhabitants.

Both the 'Nazi map' and the 'Hoaxmap' were analysed in the seminar, after an introduction to the media discourse around refugees in Germany that has recently (since New Year's Eve 2015) shifted from 'Willkommenskultur' [welcoming culture] towards more hostile utterances, even in mainstream public discourse. 
The maps were deconstructed along the following key questions:

1.) Who are the actors involved in the map's production; what narratives concerning others are involved?

2.) What are the intentions of the map's authors in disseminating the map?

3.) To what extent is the map capable of influencing individuals' modes of thought and action?

4.) Which aspects of spatial (re-)production can you find in the map? What effects do those (re-)productions have on societal cohesion and cooperation?

The method used for the map's gradual and cooperative deconstruction was 'think-pairshare' (BpB, 2012). At the beginning of the seminar, students investigated the map independently (questions 1 and 2) before discussing question 3 with a partner. Question 4 was then discussed by the entire group, also drawing on the reflexivity competence that features within education for Spatial Citizenship's (Jekel et al. 2015). Students discussed in particular the "Nazi map"s narrative and related media discourses, and how these are represented in their own lives and lived spaces.

When deconstructing the map, students focused mainly on a critical reflection on the map's manipulative layout (cf. Monmonier, 1991) and language. They were particularly critical of the language used: in the 'Nazi map' for its rudeness and inhumanity, and in the 'Hoaxmap' for the crime reports that the map debunks. Concerning the 'Nazi map', students noted that the layout was 'overpowering' (all quotations translated by the authors) and that the map was probably 'meant to evoke fear', especially due to the choices of colour and the size of the pins (the latter, however, is a pre-determined feature of Google MyMaps). The students were in favour of the 'Hoaxmap', while they were irritated by the language of the original reports and its inequality-producing conception of human beings, which they regarded as 'highly undemocratic'. They were especially critical of the racist links that some of the original reports made between the alleged perpetrators' physical characteristics and their nationality ('seemingly southern-European', Hoaxmap, 2016).

The final step in the seminar was either to develop ideas for counter-maps or to collect new starting points for creating societal counter-narratives that could possibly be used in primary school classrooms. One group came up with the idea of creating a map that focuses on cafés or public facilities that offer language tandems, where refugees could meet local people. A similar approach was followed by Pro Asyl (2016), who published a map of refugee-support institutions after the appearance of the original 'Nazi map'. This approach really does help people in need by providing orientation towards supporting institutions. Another approach was to create a draft for a story map that focuses on the pupils' biographical background and relates refugees' lifeworlds to the students' own lifeworlds. When it comes to geomediarelated communication competences, analyzing the learners' (ideological) pre-conceptions is, however, of vital importance to decide on which methods to apply in class. It can in fact be quite helpful to allow time for intense reflection on and analysis of one's own biography and the refugees' lifeworld experiences to create a new - deeper - level of understanding and reflexivity (see Maaßen, 1996, on the subject of biographical learning). 


\section{Conclusions and outlook}

Based on the example of two highly political neocartography maps, this paper has provided some refinement of the theoretical principles of the Spatial Citizenship approach that already explicitly focuses on human rights and democratic concepts as foundations of mature, lay, map production. The paper has shown how this theoretical basis aims towards a humanist ideal of society and education that is closely linked to maturity and distances itself from neoliberal and populist tendencies. Thereby, Spatial Citizenship is able to provide a framework for addressing current political issues of relevance to the students' everyday lives, linking citizenship education with the deconstruction of, and communication with and about, prominent geomedia (re-)productions in Geography classes. The relevance of this approach is not limited to addressing the emergence and strengthening of right-wing populist or extremist movements: it can also be transferred to other areas where reflexive deconstruction of discourses is needed and the relevance of counter-maps is high, e.g. the debates on manmade climate change, global food crises or gender inequality. Future work will provide learning environments around these topics while constantly re-assessing the adequacy of the Spatial Citizenship's theoretical and normative background, developing it even further if necessary within the conflict area of interest, communication, activism and humanist concepts of society.

\section{References}

Adorno, T.W. (1971). Erziehung zur Mündigkeit. Vorträge und Gespräche mit Hellmut Becker 1959 bis 1969. Berlin: Suhrkamp.

Albernathy, D. (2017). Using Geodata \& Geolocation in the Social Sciences. Mapping Our Connected World. London, Thousand Oaks, New Delhi, Singapore: SAGE.

Arab Charter on Human Rights (2006). Arab Charta on Human Rights. In: Boston University Law Journal, 24 (147), 147-164.

Baumfeld, L. \& Plicka, P. (2006). Großgruppeninterventionen - das Praxisbuch. Wien: ÖARRegionalberatung $\mathrm{GmbH}$.

Bennett, W. L., Wells, C., Rank, A. (2009): Young citizens and civic learning: Two paradigms of citizenship in the digital age. In: Citizenship Studies, 13 (2), 105-120.

Bundesministerium des Inneren (BMI) (2015): Fragen zur polizeilichen Lagebilderstellung von Anschlägen gegen Flüchtlingsunterkünfte. Drucksache 18/7000: Antwort der Bundesregierung auf die kleine Anfrage der Abgeordneten Monika Lazar, Luise Amtsberg, Volker Beck (Köln), weiterer Abgeordneter und der Fraktion BÜNDNIS 90/DIE GRÜNEN- Drucksache 18/6513 Deutscher Bundestag. Retrieved from http://dip21.bundestag.de/dip21/btd/18/070/1807000.pdf

Bundeszentrale für politische bildung (BPB) (2012). Think-Pair-Share. Retrieved from http://www.bpb.de/lernen/grafstat/grafstat-bundestagswahl-2013/148908/think-pair-share

Elwood, S. \& K. Mitchell (2013). Another Politics Is Possible. Neogeographies, Visual Spatial Tactics, and Political For-mation. In: Cartographica, 48 (4), 275-292.

Friz, K. (2015). Alle Asylbewerberheime auf einen Blick. Retrieved from http:/ / www.faz.net/aktuell/feuilleton/umstrittene-karte-mit-asylbewerberheimen-auf-google13705931.html

Grammes, T. (2005). Kontroversität. In: Sander, W. (Ed.): Handbuch politische Bildung. Schwalbach: Wochenschau, 126-145. 
Gryl, I., Scharf, C., Weis, S. \& Schulze, U. (2017). Geomedia and the Space in Between. Georeferencing, Non-localisation, and Glocalisation. GI_Forum 2017/2, 49 - 59. DOI: 10.1553/giscience2017_02_s49

Gryl, I. \& Jekel, T. (2012). Re-centering GI in secondary education: Towards a spatial citizenship approach. Cartographica, 47 (1), 18-28.

Habermas, J. (1970): Erkenntnis und Interesse. Frankfurt a. M.: Suhrkamp.

Harley, J.B. (1989). Deconstructing the map. In: Cartographica, 26 (2), 1-20.

Hart, R.A. (1997). Children's participation: the theory and practice of involving young citizens in community development and environmental care. New York, London: Earthscan.

Schwarz, K. \& Häußer, D. (2016). Hoaxmap. Retrieved from http://hoaxmap.org.

Hollmer, K. (2015). Die braune Landkarte. Retrieved from http://jetzt.sueddeutsche.de/texte/anzeigen/593682/Die-braune-Landkarte.

Jekel, T., Gryl, I. \& Oberrauch, A. (2015). Education for Spatial Citizenship: Versuch einer Einordnung. In: GW Unterricht, 137 (1), 5-13.

Johnson, L. \& Morris, P. (2010). Towards a framework for critical citizenship education,

Curriculum Journal, 21 (1), 77-96.

Lefebvre, H. (1993). The production of space. Oxford: Blackwell.

Liessmann, K. (2011). Die letzte Aufgabe unseres Daseins. Über Bildung und ihre Deformation im Zeitalter des Wissens. In: Sandoval, M., S. Sevignani, A. Rehbogen, Th. Allmer, M. Hager \& V. Kreilinger (Eds.): Bildung MACHT Gesellschaft. Münster: Verlag Westfälisches Dampfboot, 39_ 50 .

Luhmann, N. (1998). Die Wissenschaft der Gesellschaft. Frankfurt a. M.: Suhrkamp.

Maaßen, B. (1996). Das Subjekt des biographischen Lernens. In: Schulz, W. (Ed.): Lebensgeschichten und Lernwege. Baltmannsweiler: Schneider-Verlag Hohengehren, 23-36.

Monmonier, M.S. (1991). How to lie with maps. Chicago, London.

Münkler, H. (2002). Die neuen Kriege. Reinbek: Rowohlt.

Peluso, N.L. (1995). Whose Woods are These? Counter-Mapping Forest Territories in Kalimantan, Indonesia. Antipode, 27 (4), 383-406.

Pokraka, J., Könen, D., Gryl, I. \& Jekel, T. (2016). Raum und Gesellschaft: Spatial Citizenship als Integration von Medien-, geographischer und politischer Bildung. In: Kuckuck, M. \& Budke, A. (Eds.): Politische Bildung im Geographieunterricht. Stuttgart: Franz Steiner, 77-87.

Pro Asyl (2016). Ehrenamtliches Engagement. Online Via: https://www.proasyl.de/ehrenamtlichesengagement/

Reinbold, F. (2015): Muss Google Karte mit Flüchtlingsheimen löschen? Retrieved from http://www.spiegel.de/netzwelt/web/asylbewerber-muss-google-karte-mit-fluechtlingsheimenloeschen-a-1043845.html

Riedel, E. (2004). Der internationale Menschenrechtsschutz. Eine Einführung. In: Bundeszentrale für politische Bildung (Ed.): Menschenrechte. Dokumente und Deklarationen. Bonn: Bundeszentrale für politische Bildung, 11-40.

Schulz, J. (2015): Wie eine Anleitung zur Gewalt. Retrieved from http://www.taz.de/!5213639/

Schulze, U., Gryl, I. \& Kanwischer, D. (2015). Spatial Citizenship education and digital geomedia: composing competences for teacher education and training. In: Journal of Geography in Higher Education, 39 (3), 369-385.

Turnbull, D. (1998). Mapping encounters and (en)countering maps: A critical examination of cartographic resistance. In: Knowledge and Society, 11, 15-44.

Weißeno G., Detjen, J., Juchler, I., Massing, P. \& Richter, D. (2009). Konzepte der Politik. Ein Kompetenzmodell. Bonn: Bundeszentrale für politische Bildung.

Wirsching, A. (2016): Demokratie und Globalisierung. Europa seit 1989. München: C.H. Beck.

Zeit Online (Ed.) (2015). Google löscht Flüchtlingsheim-Karte. Retrieved from http://www.zeit.de/digital/internet/2015-07/google-maps-asylbewerheime-nazis-geloescht 